\title{
ANALISIS ISI LAMBUNG IKAN TAWES (Barbonymus gonionotus) DI HILIR SUNGAI BENGAWAN SOLO KABUPATEN LAMONGAN
}

\section{Analysis of Silver Barb (Barbonymus gonionotus) gut content in Bengawan Solo River Estuary, Lamongan Regency}

Nanik Retno Buwono ${ }^{1 *}$,Diana Arfiati ${ }^{1}$, dan Muhammad Samsul Arifin ${ }^{2}$

${ }^{1}$ Program Studi Program Studi Manajemen Sumberdaya Perairan, Fakultas Perikanan dan Ilmu Kelautan, Universitas Brawijaya

${ }^{2}$ Departemen Manajemen Sumberdaya Perairan, Fakultas Perikanan dan Ilmu Kelautan, Universitas Brawijaya

*buwonoretno@ub.ac.id

\begin{abstract}
Abstrak
Analisis isi lambung ikan dapat memberikan gambaran antara komposisi pakan alami dalam lambung dengan habitatnya. Tujuan penelitian ini untuk mendeskripsikan mengenai makanan alami ikan Tawes (Barbonymus gonionotus) dengan melihat isi lambung ikan, pola pertumbuhan dan faktor kondisi ikan di bagian hilir Sungai Bengawan Solo Kabupaten Lamongan. Metode yang digunakan dalam penelitian ini adalah metode survey dengan pengambilan sampel dua minggu sekali selama 2 bulan. Hasil penelitian yang diperoleh menunjukkan bahwa ikan tawes merupakan ikan herbivora. Rasio panjang relatif usus ikan tawes berkisar antara 2,0-2,1 cm yaitu panjang usus ikan tawes lebih panjang dari panjang total tubuhnya yang menunjukkan ikan tawes bersifat herbivora. Frekuensi kejadian makanan ikan tawes didominasi dari jenis plankton Chlorophyta yaitu Akistrodesmus (100\%) pada semua lambung yang teramati serta Ulotrix $(94,4 \%)$ yang ditemukan di beberapa lambung yang teramati. Kisaran panjang tubuh ikan tawes antara 104,8-280,1gram dan memiliki pola pertumbuhan allometrik negatif. Faktor kondisi pada ikan tawes betina dengan nilai rata-rata 1,4 dan pada ikan tawes jantan dengan nilai rata-rata 0,8. Faktor kondisi ikan tawes di Sungai Bengawan Solo memiliki faktor kondisi yang cukup tinggi hal ini berarti adanya kecocokan antara ikan dengan lingkungannya.
\end{abstract}

Kata kunci: Barbonymus gonionotus, Sungai Bengawan Solo, analisis lambung

\begin{abstract}
Analysis of fish gut contents can provide an overview of the composition of natural feed in the stomach with its habitat. The purpose of this study is to describe the natural food of Tawes fish (Barbonymus gonionotus) by looking at fish gastric contents, growth patterns and factors of fish conditions in the lower reaches of the Bengawan Solo River in Lamongan Regency. The method used in this study is a survey method with sampling every two weeks for 2 months. The results obtained showed that tawes fish were herbivorous fish. The ratio of the relative length of tawes fishintestines ranged from 2,0-2,1 cm, which was longer than the total length of the body which showed that tawes were herbivorous. The frequency of occurrence of tawes fish was dominated by Chlorophyta plankton species, namely Akistrodesmus (100\%) on all stomachs observed and Ulotrix (94,4\%) found in several stomachs observed. The range of body length of tawes fish is 104.8-280.1 grams and has an allometric negative growth pattern. The condition factors in female tawes fish that average value 1,4 and in male tawes fish average value 0,8 . The condition of the condition of tawes fish in the Bengawan Solo River has a fairly high factor, this means that there is a match between the fish and the environment.
\end{abstract}

Keywords : Barbonymus gonionotus, Bengawan Solo River, stomach analysis

\section{PENDAHULUAN}

Ikan Tawes (Barbonymus gonionotus) di bagian hilir Sungai Bengawan Solo Kabupaten Lamongan banyak ditangkap oleh masyarakat sekitar dengan menggunakan alat tangkap anco dan juga prayang. Hasil survei pendahuluan menunjukkan ikan yang banyak tertangkap oleh nelayan didominasi oleh ikan tawes. Ikan tawes merupakan ikan air tawar dengan nilai ekonomis yang cukup tinggi, sehingga para nelayan selalu melakukan kegiatan penangkapan secara terus menerus setiap waktu dan tidak mengenal musim.

Kondisi perairan di Sungai Bengawan Solo dari beberapa penelitian menun- 
jukkan kualitas perairan yang terus mengalami penurunan (Riyatun et al., 2004). Berdasarkan kondisi tersebut perlu dilakukan upaya untuk pelestarian sumberdaya ikan yang ada di Sungai Bengawan Solo seperti ikan tawes. Salah satu usaha pelestarian yang dapat dilakukan adalah dengan domestikasi atau pembudidayaan. Aspek biologi yang dapat digunakan untuk domestikasi adalah mengetahui kebiasaan makan dari ikan tersebut seperti makanan alami yang disukai. Menurut Dolgov (2007), makanan yang disukai oleh ikan dengan jenis yang sama akan berbeda tergantung dari kebiasaan dan habitatnya.

Populasi ikan tawes di Sungai Bengawan Solo semakin lama semakin menurun. Selain dari faktor kondisi perairan juga disebabkan oleh kegiatan penangkapan oleh nelayan di sepanjang Sungai Bengawan Solo yang selalu menangkap ikan secara terus-menerus. Faktor yang lain dapat disebabkan oleh berbagai aktivitas masyarakat yang tinggal di sekitar Sungai Bengawan Solo. Kegiatan masyarakat tersebut mempengaruhi kondisi biotik perairan dan kemungkinan ketersediaan makanan alami ikan disungai ini terjadi pengurangan dan terganggu sehingga kehidupan ikan tawes ini juga terancam. Berdasarkan hal tersebut maka perlu meneliti analisis isi lambung ikan tawes di bagian hilir Sungai Bengawan Solo Lamongan untuk mengetahui kebiasaan makan dari jenis ikan tersebut.

\section{METODOLOGI}

\section{Materi Penelitian}

Materi penelitian dalam penelitian ini terdiri dari alat dan bahan yang digunakan dalam penelitian. Peralatan yang digunakan dalam penelitian ini adalah timbangan digital (ketelitian 0,01 gram), botol film, mikroskop, coolbox, cawan petri, haemocytometer, pipet tetes, hecting set, tally counter, nampan, talenan, gelas ukur, kamera dan alat tulis.

Bahan yang digunakan dalam penelitian ini adalah ikan tawes yang diperoleh dari lokasi penelitian, formalin
$4 \%$, aquades, kertas label, es batu dan tisu.

\section{Metode Penelitian}

Metode yang digunakan pada penelitian ini adalah dengan metode survei. Pengambilan titik sampling dibagi menjadi 3 lokasi. Titik Sampling 1 di Desa Dinoyo Kecamatan Deket dengan letak geografis $7^{\circ}$ 6'11.21"LS dan 112²6'20.46"BT. Titik Sampling 2 di Desa Blawi Kecamatan Karangbinangun dengan letak geografis $7^{\circ} 4^{\prime} 46.70^{\prime \prime} L S$ dan $112^{\circ} 26^{\prime} 41.12^{\prime \prime} B T$. Titik Sampling 3 di Desa Glagah Kecamatan Glagah Kabupaten Lamongan dengan letak geografis $7^{\circ} 2^{\prime} 37.96$ "LS dan $112^{\circ} 27^{\prime} 16.03^{\prime \prime}$ BT.

Pengambilan sampel ikan tawes dilakukan selama dua minggu sekali sebanyak 4 kali ulangan. Sampel ikan yang telah diambil untuk diukur panjang dan beratnya serta diambil lambungnya, selanjutnya lambung ikan tawes disimpan dalam coolbox yang sudah berisi es batu. Kemudian jenis pakan alami diamati di laboratorium Reproduksi ikan Universitas Brawijaya Malang, Jawa Timur.

Menurut Effendie (1997), analisis lambung ikan dapat dilakukan dengan pengamatan atau identifikasi dalam keadaan segar. Lambung ikan dipisahkan dari dalam tubuh ikan kemudian isi lambung dikeluarkan dan diukur berat dan volumenya. Untuk jenis makanan dalam lambung dapat diamati secara langsung dengan mikroskop untuk memperjelas untuk jenis makanan yang berukuran mikro.

\section{Analisis Hubungan Panjang dan Berat}

Hubungan panjang berat ikan menurut Fuadi (2016) menggunakan persamaan sebagai berikut:

$$
\mathrm{W}=\mathrm{aL}^{\mathrm{b}}
$$

Keterangan:

$\mathrm{W}=$ Berat ikan (gram)

$\mathrm{L}=$ Panjang ikan $(\mathrm{cm})$

$\mathrm{a}=$ Intercept regresi linier

$\mathrm{b}=$ Koefisien regresi

Persamaan tersebut dilinierkan dengan fungsi logaritma sebagai berikut :

$$
\log W=\log a+b \log L
$$


Jika nilai $b=3$ maka pertumbuhan ikan bersifat isometrik yaitu pertambahan berat ikan sama dengan pertambahan panjang ikan. Jika nilai $b \neq 3$ maka partumbuhan ikan bersifat allometrik. Pertambahan berat ikan lebih cepat daripada pertambahan panjang disebut allometrik positif (b>3) sedangkan pertambahan panjang ikan lebih cepat daripada pertambahan beratnya disebut allometrik negatif $(b<3)$.

\section{Analisis Faktor Kondisi Ikan}

Menurut Febrianti (2013), faktor kondisi ikan dihitung berdasarkan panjang dan berat ikan apabila nilai $b \neq 3$ (bersifat allometrik) dengan menggunakan rumus:

Keterangan:

$$
\mathrm{FK}=\frac{\mathrm{W}}{\mathrm{aL}^{\mathrm{b}}}
$$

$\mathrm{FK}=$ Faktor kondisi

$\mathrm{W}=$ Berat rata-rata ikan (gram)

$\mathrm{L}=$ Panjang rata-rata ikan $(\mathrm{cm})$

$\mathrm{a}, \mathrm{b}=$ konstanta

\section{Frekuensi Kejadian Makanan}

Menurut Effendie (1997) metode frekuensi kejadian dilakukan dengan mengidentifikasi semua isi lambung dan mencatatnya sebagai bahan makanan bahkan saat lambungnya kosong. Tiap-tiap jenis makanan yang ditemukan dihitung dengan rumus sebagai berikut :

Keterangan:

$$
\mathrm{Fi}=\frac{\mathrm{ni}}{\mathrm{n}} \times 100 \%
$$

$\mathrm{F}_{\mathrm{i}}=$ Frekuensi kejadian

$\mathrm{n}_{\mathrm{i}}=$ jumlah lambung yang mengandung jenis makanan $\mathrm{i}$

$\mathrm{n}=$ jumlah total lambung

\section{Rasio Panjang Saluran Pencernaan dengan Panjang Total Ikan}

Panjang saluran pencernaan ikan diukur mulai ujung pangkal faring hingga ujung usus, sedangkan panjang total ikan diukur mulai ujung depan mulut hingga ujung sirip ekor paling belakang. Menurut Hariati (1989), rumus menghitung rasio panjang saluran pencernaan dengan panjang total tubuh ikan adalah sebagai berikut :

$$
\mathrm{R}=\frac{\text { Panjang saluran pencernaan ikan }(\mathrm{cm})}{\text { Panjang total tubuh ikan }(\mathrm{cm})}
$$

Keterangan :

$\mathrm{R}=$ Rasio panjang saluran pencernaan dengan total panjang tubuh ikan

Jika $\mathrm{R}=0,2-2,5 \mathrm{~cm}$ merupakan golongan ikan karnivora; $\mathrm{R}=0,6-8,0 \mathrm{~cm}$ merupakan golongan ikan omnivora dan $\mathrm{R}$ $=0,8-15 \mathrm{~cm}$ merupakan golongan ikan herbivora.

\section{Analisis Parameter Kualitas Air}

Parameter kualitas air yang diukur pada penelitian adalah suhu perairan dengan menggunakan thermometer $\mathrm{Hg}$, parameter kecerahan perairan dengan secchi disk dan $\mathrm{pH}$ perairan dengan menggunakan $\mathrm{pH}$ meter.

\section{HASIL DAN PEMBAHASAN Hubungan Panjang Berat Ikan Tawes (Barbonymus gonionotus)}

Analisis hubungan panjang berat dalam penelitian ini dilakukan terhadap ikan tawes jantan dan ikan tawes betina. Analisis hubungan panjang berat ikan tawes jantan menunjukkan pola pertumbuhan allometrik negatif (Gambar 1).

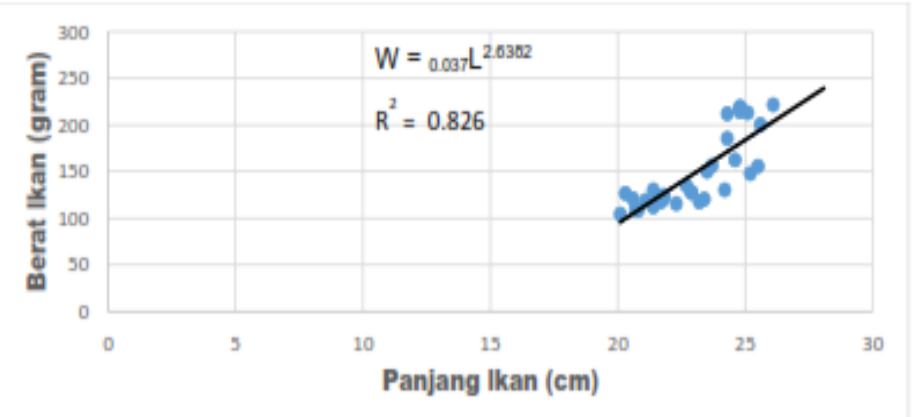

Gambar 1. Grafik hubungan panjang dan berat ikan tawes jantan 
Berdasarkan hasil analisis tersebut diperoleh nilai konstanta $\mathrm{b}=2,64$ dan termasuk pada pertumbuhan yang pertambahan panjang lebih dominan daripada pertambahan berat karena nilai $b<3$. Hasil analisis hubungan panjang dan berat ikan tawes betina memperoleh nilai $\mathrm{b}=2,78$ atau nilai $\mathrm{b}<3$ dengan pola pertumbuhan allometrik negatif (Gambar 2).

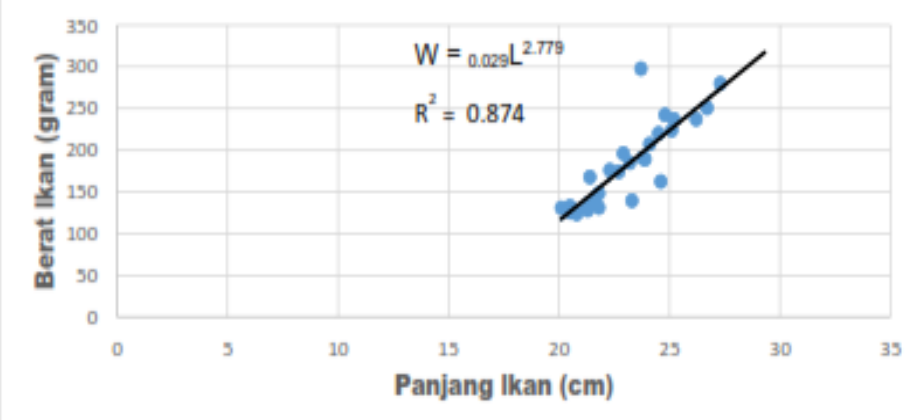

Gambar 2. Grafik hubungan panjang dan berat ikan tawes betina

Ikan tawes jantan dan ikan tawes betina di bagian hilir Sungai Bengawan Solo memiliki pola pertumbuhan yang sama yaitu allometrik negatif. Menurut Wahyudewantoro dan Haryono (2013), ikan dengan pola pertumbuhan allometrik negatif termasuk ikan yang bergerak aktif yang mengakibatkan energi yang dibutuhkan untuk bergerak lebih besar dibandingkan untuk kebutuhan yang lain sehingga ikan relatif lebih cepat bertambah panjang daripada bertambah berat. Sedangkan untuk nilai $b$ yang diperoleh berbeda dari ikan tawes jantan dan ikan tawes betina. Menurut Purnomo et al. (2005), nilai konstanta $b$ dari spesies ikan dapat dipengaruhi oleh faktor internal yaitu perbedaan umur, jenis kelamin, tingkat kematangan gonad, tingkat kepenuhan lambung dan juga faktor eksternal yaitu musim, letak geografis, parasit serta penyakit.

\section{Faktor Kondisi Ikan Tawes (Barbonymus gonionotus)}

Faktor kondisi ikan tawes jantan memiliki nilai rata-rata 0,84 sedangkan faktor kondisi ikan tawes betina dengan nilai rata-rata 1,4 . Nilai faktor kondisi ikan 0-1 menunjukkan ikan dalam keadaan kurus (Febrianti, 2013). Menurut Fuadi (2016), faktor yang mempengaruhi nilai faktor kondisi adalah jumlah organisme, kondisi organisme, ketersediaan makanan yang ada dalam lingkungan perairan serta kualitas dari perairan itu sendiri. Nilai faktor kondisi yang tinggi menunjukkan adanya kecocokan antara ikan dengan lingkungan habitat hidupnya.

\section{Rasio Panjang Usus dengan Panjang Total Ikan Tawes (B. gonionotus)}

Nilai perbandingan antara panjang total tubuh ikan dengan panjang total usus ikan dapat digunakan untuk mengetahui kebiasaan makan ikan tersebut seperti herbivora, omnivora dan karnivora. Struktur saluran pencernaan ikan tawes dapat dilihat pada Gambar 3. Hasil pengukuran rasio rata-rata panjang usus dengan panjang total ikan tawes atau panjang usus relatif disajikan pada Tabel 1 berikut :

Tabel 1. Rasio rata-rata panjang usus relatif ikan tawes $(\mathrm{cm})$

\begin{tabular}{lccc}
\hline Stasiun & P.total & P.Usus & P.Usus Relatif \\
\hline 1 & 22,9 & 46,3 & 2,0 \\
2 & 23,0 & 47,1 & 2,1 \\
3 & 23,2 & 46,7 & 2,0 \\
\hline
\end{tabular}


Berdasarkan hasil data pada Tabel 1, panjang relatif usus ikan tawes berkisar antara 2,0-2,1 cm yang menunjukkan bahwa panjang usus ikan tawes lebih panjang daripada panjang totalnya sehingga ikan tawes dapat digolongkan bersifat herbivora. Menurut Handajani dan Wahyu (2010), panjang usus ikan sangat bervariasi serta berhubungan erat dengan kebiasaan makanannya. Jenis ikan herbivora memiliki panjang usus beberapa kali dari panjang tubuhnya sehingga posisi usus melingkar - lingkar di dalam perut ikan.

\section{Frekuensi Kejadian Makanan}

Frekuensi kejadian tertinggi seluruh stasiun pada semua ikan yang tertangkap dari genus Ankistrodesmus sebesar $100 \%$ kemudian yang terendah oleh genus Cyclotella, Chrococcus, dan Merimopedia sebesar $1,9 \%$. dan yang tidak teridentifikasi berupa serasah $2,5 \%$ yang diduga ikut termakan (Gambar 4).

Berdasarkan hasil Gambar 4 dapat diketahui bahwa jenis plankton Chlorophyta memiliki nilai frekuensi kejadian yang paling tinggi yakni berkisar $74,1 \%$ dan terendah pada jenis plankton Chrysophyta yakni sebesar $6,4 \%$ dan $2,5 \%$ serasah. Perbedaan konsumsi makanan alami ini dikarenakan jenis plankton Chlorophyta atau yang sering dikenal sebagai alga hijau memiliki struktur yang hampir sama dengan tumbuhan salah satunya ialah dinding sel yang tersusun atas selulosa dan kemungkinan adanya dominasi di perairan pada genera dari jenis plankton chlorophyta yaitu Ankistrodesmus dan Ulotrix yang ditemukan dalam jumlah banyak pada semua lambung yang teramati.

Menurut Kasim (2005), Chlorophyta merupakan alga yang mampu mensintesa makanan sendiri dengan bantuan sinar matahari karena mempunyai klorofil dan biasanya berwarna hijau, sehingga disebut alga hijau (Green Algae), dengan contoh spesies : Ulothrix sp., Chlomydomnas sp., Scenedesmus sp., Pediastrum sp., Eudorina sp., dan Ankistrodesmus sp.

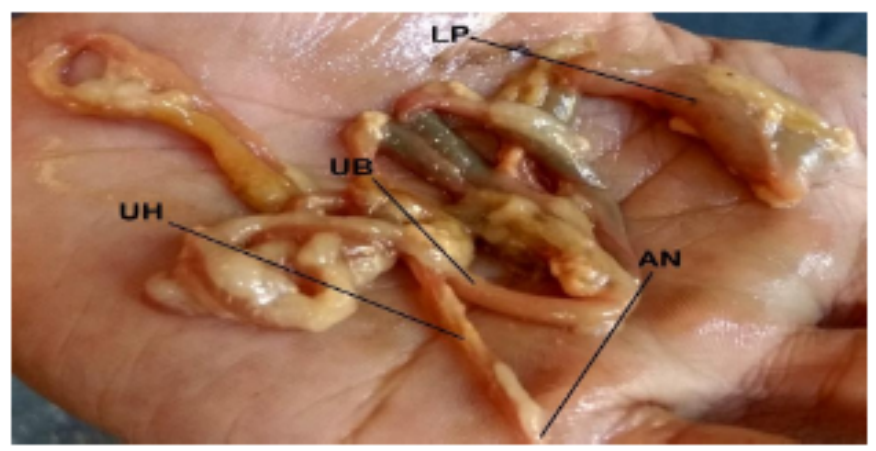

Gambar 3. Struktur saluran pencernaan ikan tawes. LP) Lambung Palsu, UB) usus Besar, UH) usus halus dan AN) anus

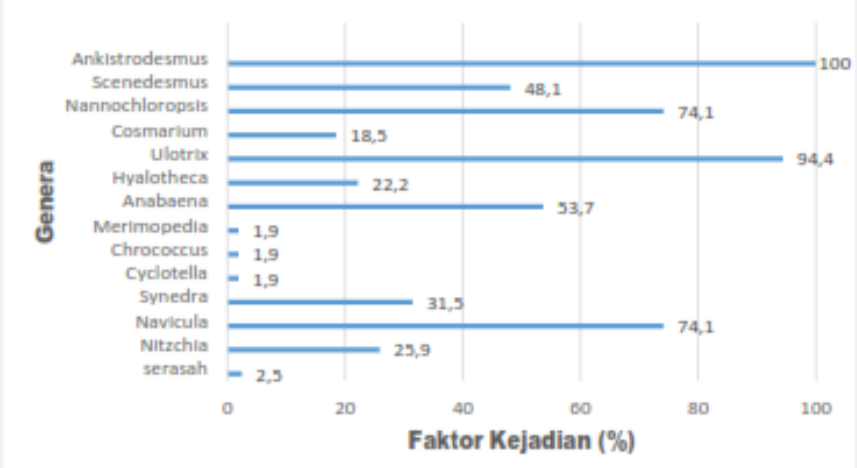

Gambar 4. Frekuensi kejadian total makanan pada lambung ikan tawes 


\section{Parameter Kualitas Air}

Kualitas perairan merupakan parameter penunjang bagi kehidupan ikan. Kualitas perairan yang buruk dapat mengakibatkan terganggunya nafsu makan ikan sehingga dapat mempengaruhi pertumbuh- an ikan tersebut. Parameter yang diamati pada penelitian ini meliputi parameter suhu, $\mathrm{pH}$, kecerahan dan dissolved oxygen (DO). Hasil pengamatan kualitas perairan dapat dilihat pada Tabel 2 .

Tabel 2. Parameter kualitas air bagian hilir sungai Bengawan Solo

\begin{tabular}{llccc}
\hline No. & Parameter & Stasiun 1 & Stasiun 2 & Stasiun 3 \\
\hline 1. & Suhu $\left({ }^{0} \mathrm{C}\right)$ & 27 & 27 & 28 \\
2. & Kecerahan & 22,33 & 21 & 22 \\
& $(\mathrm{~cm})$ & & & \\
3. & pH & 7 & 7 & 7 \\
4. & DO $(\mathrm{mg} / \mathrm{L})$ & 7,62 & 7,64 & 7,74 \\
\hline
\end{tabular}

Kisaran suhu yang diperoleh selama penelitian yaitu berkisar antara $27-28^{\circ} \mathrm{C}$. Menurut Affan (2011), kisaran suhu yang baik bagi kehidupan organisme akuatik yaitu berkisar antara $20-32^{\circ} \mathrm{C}$. Peningkatan suhu dapat menurunkan kelarutan oksigen sehingga mempengaruhi proses metabolisme.

Kecerahan di bagian hilir Sungai Bengawan Solo pada setiap stasiun berkisar antara 21-22,33 cm. Menurut Fardiaz (1992), padatan tersuspensi akan mengurangi penetrasi cahaya ke dalam air seperti contoh air buangan sering mengandung molekul sabun, deterjen dan surfaktan yang larut air, misalnya pada air buangan rumah tangga dan industri pencucian.

Nilai $\mathrm{pH}$ pada semua stasiun adalah 7 atau perairan dalam kondisi netral. Menurut Gazali et al. (2013), batas pH yang diperbolehkan untuk kegiatan pengairan maupun kegiatan yang lain berkisar antara 5-9. Nilai DO pada setiap stasiun berkisar antara 7,62-7,74 mg/L. Menurut Lukman (2014), kebutuhan oksigen terlarut yang dibutuhkan ikan yaitu minimal $4 \mathrm{mg} / \mathrm{l}$. Oksigen terlarut yang ideal untuk pertumbuhan ikan yaitu lebih dari $5 \mathrm{mg} / \mathrm{l}$.

\section{KESIMPULAN DAN SARAN Kesimpulan}

Berdasarkan hasil penelitian diperoleh kesimpulan ikan tawes merupakan golongan ikan herbivora. Data menunjukkan panjang relatif usus ikan tawes berkisar antara 2,0-2,1 cm yang menunjukkan bahwa panjang usus ikan tawes lebih panjang daripada panjang totalnya.

Frekuensi kejadian makanan ikan tawes didominasi dari jenis plankton Chlorophyta yaitu Akistrodesmus (100\%) pada semua lambung yang teramati serta Ulotrix $(94,4 \%)$ yang ditemukan di beberapa lambung yang teramati. Kualitas air disetiap stasiun masih layak untuk pertumbuhan dan kehidupan ikan. Perlu adanya penelitian lanjutan mengenai makanan alami ikan tawes dengan membandingkan keberadaan di lingkungan perairannya.

\section{DAFTAR PUSTAKA}

Affan, J. M., 2011. Seleksi Lokasi Pengembangan Budidaya dalam Keramba Jaring Apung (KJA) Berdasarkan Faktor Lingkungan dan Kualitas Air di Perairan Pantai Timur Kabupaten Bangka Tengah. J. Sains MIPA 17(3), pp. 99-106.

Dolgov, A. V., 2007. Trophic structure of the barents Sea Fish community with the special reference to the cod stock recovery ability. ICES C.M D:08.

Effendie, H., 1997. Biologi Perikanan. Yayasan Pustaka Nusantara Yogyakarta.

Fardiaz, S., 1992. Polusi Air dan Udara. Kanisius Yogyakarta. 
Febrianti, A., 2013. Kajian Kondisi kan Selar (Selaroides leptolepis) Berdasarkan Hubungan Panjang Berat dan Faktor Kondisi di Laut Natuna yang Didaratkan di Tempat Pendaratan Ikan Pelantar KUD Tanjungpinang. Jurnal Umrah 8.

Fuadi, Z., 2016. Hubungan Panjang Berat Ikan yang Tertangkap di Krueng Simpoe, Kabupaten Bireun, Aceh. Jurnal Ilmiah Mahasiswa Kelautan dan Perikanan Unsyiah 1(1), pp. 169-176.

Gazali, I., Widiatmono, Rahadi, B., and Wirosoedarmo, R. 2013. Evaluasi Pencemaran Air Dampak Pembuangan Limbah Cair Pabrik Kertas Terhadap Kualitas Air Sungai Klinter Kabupaten Nganjuk. Jurnal Keteknikan Pertanian Tropis dan Biosistem 1(2),pp. 1-8.

Handajani, H., and Wahyu, W., 2010. Nutrisi Ikan. UMM Press Malang.

Hariati, A. M., 1989. Makanan Ikan. Universitas Brawijaya Press Malang.

Kasim, M., 2005. Lingkungan Ekosistem Pesisir Mengenal Diatom (READY) website.

http://maruf.wordpress.com/2005/1 2/22/mengenal-diatom.

Lukman., 2014. Efektivitas Pemberian Akar tuba (Derris elliptica) Terhadap Lama Waktu Kematian Ikan Nila (Oreochromis nilloticus). Jurnal Pertanian 5(1), pp. 22-31.

Purnomo, K., Kartamiharja, S. E., 2005. Pertumbuhan Mortalitas, dan Kebiasaan Makan Ikan Tawes (Barbodes gonionotus) di Waduk Wonogiri. Jurnal Penelitian Perikanan Indonesia 11(2), pp. 1-8.

Riyatun, S. W., Sugiarti, A. D., Wijaya, and Sarjono, Y. 2004. Indikasi Pencemaran Merkuri (Hg) di Sungai Bengawan Solo. BioSmart 6(2),pp. 138-142.

Wahyudewantoro, G. and Haryono., 2013. Hubungan Panjang Berat dan Faktor Kondisi Ikan Belanak (Liza subrividis) di Perairan Taman Nasional Ujung Kulon-Pandeglang, Banten. Jurnal Ilmu-Ilmu Hayati dan Fisik 13(3): 173-178. 